\title{
The Question of Humanism: A Radical Humanist Reading of The Select Novels of Cormac McCarthy
}

\author{
Sakti Sekhar Dash \\ Ravenshaw University \\ Cuttack, Odisha, India \\ saktisekhardash96@gmail.com
}

\section{Objective}

The objective of this study is to find out the recurring theme of virtue, violence and radical humanism in the novels Blood Meridian and The Road The Road by Cormac McCarthy. As a novelist, McCarthy has explored many different issues, but the issues of virtue, violence, and radical humanism, which have got new dynamics, remain to be explored.

\section{Research Methodology}

The research methodology involves a close reading of McCarthy's novels. It includes analyzing them in a critical manner. An inter-textual reading of his novels is needed to shed light on the aspects of his novels.

Review of Literature

As a novelist, Cormac McCarthy explores different ideas and perspectives. He forges a world of horror and violence in his Southern Gothic masterpiece, Child of God. In the Blood Meridian, The Border Trilogy and No Country for Old Men, he delves into the mythic West. But 
his writing takes a different turn in The Road, where he depicts a post-apocalyptic world. Traditionally, the research on Cormac McCarthy has focused on his Western myths, his concerns with the frontier, the role of folklore and morality and the position of God in his world. In his work, titled Trauma and Mythologies of the Old West in the Western Novels of Cormac McCarthy (2012) Antony Harrison explores the interdependency of myth and trauma to explain the repetitive cycles of loss, failure and defeat that pervade McCarthy's works. Similarly, Lydia R. Cooper in her paper titled He is a psychopathic Killer, but so what?: Folklore and Morality in Cormac McCarthy's No Country for Old Men (2013) analyzes the dynamics of traditional Western Folklore and morality. God, Evil and Truth in Cormac McCarthy's Blood Meridian and The Crossing (2017) by Stanciu Elena Laris examines the existence of God in Billy Parham's world. Borrowed Time, Borrowed World and Borrowed Eyes: Care, Ruin and Vision in McCarthy's The Road and Harrison's Ecocriticism (2010) by Ben de Bryun analyzes McCarthy's post-apocalyptic masterpiece The Road in the context of ecocriticism. Berit Astrom interprets The Road as a post-feminist text in Postfeminist Fatherhood and the Marginalization of the Mother in Cormac McCarthy's The Road (2014).

Despite many critics and scholars mentioning about the extreme violence in the works of McCarthy, they have not sought to identify the underlying condition. I intend to analyze the issue of virtue and violence in the select novels of Cormac McCarthy. For the purpose, I intend to examine them in the light of radical humanism, which can explain the arbitrary nature of virtue and violence in McCarthy's creations.

Abstract

Cormac McCarthy has often been hailed as a writer's writer. His writings are difficult to classify as they evoke a complex perspective. A recurring problem in his novels is the ambiguous 
nature of virtue and violence. It is my aim to look into their dynamics in the context of radical humanism. It will shed light on human nature as presented by McCarthy, with its aspects of virtue and violence. In a world increasingly suffering from violence, where individuals strive for freedom it is important to address the question of radical humanism and its interaction with primal human nature, virtue and violence. A common thread is represented by various questions regarding human nature, free will, pure evil, nature of God, level of morality, language and meaning. The characters have little or no capacity of mind or consciousness and their encounter with the world is not mediated by laws of morality, politics or religion. In other words, the world we are facing "is void of moral meaning", it is a world that gravitates around a nihilistic core, a "morally nihilistic world."

Keywords: Virtue, Violence, Morality, Free will, Radical Humanism

Introduction

The fullest and most explicit definition that Erich Fromm gives of radical humanism is found in You Shall be as Gods. Here he explains that:

By radical humanism, I refer to a global philosophy which emphasizes the oneness of the human race, the capacity of man to develop his own powers and to arrive at inner harmony and at the establishment of a peaceful world. Radical humanism considers the goal of man to be that of complete independence and this implies penetrating through fictions and illusions to full awareness of reality (Fromm 13).

In McCarthy's The Road, one can begin by seeing its radical humanism. The only agents left in the world are a few desperate humans, and perhaps the stray dog or animal attached to them, searching for some patch of life-sustaining geography. It deals squarely with human concerns and 
lives. Nature and the world have melted away, so that not even color exists. The terms of good and bad, of morality itself, are also radicalized. "Although one may consider humanity the creator and bearer of ethical horizons, different cultures have had different notions of moral community. These can include gods, rocks, animals, and the wider world. Our relation with the rest of existence has always been fluid, or at least, alive with fluid possibilities" (Durkin 37). Yet here, such possibilities are gone. What can humans do, good or bad, to a biology and botany that no longer exist? Goodness now refers only to activities done to another human and evil follows this paradigm as well. The worst moral offense, at least for the man and boy, is not killing another. While many of his works can be read as nihilistic, in that McCarthy's novels depict a world without any divine (depending on an idea of God's purpose or will) or natural moral order. A key aspect of radical humanism involves the revolt of man against God and his agents on earth.

Most of McCarthy's works are a blend of virtue and violence. "McCarthy is concerned with the just and unjust, courage and temerity, and not with categorical imperatives, moral formulas or bourgeois conventions. Instead, his vision is prescriptive of human identity, of the virtuous states of character necessary to face the tragedy inherent to life" (Hage 16). The order created by McCarthy does not hinge on virtue and violence. It can simply be dubbed as amoral. The amorality can be explained by the characters' affiliations. Someone like Lester Ballard indulges in violence simply because he makes a choice to lead a violent life. The Man in The Road acts violently as his very survival depends on it. Cary Wolfe reveals how humanism convinces us that to be human means to be something greater than the physical body we inhabit. Humanism is concerned chiefly with an existence based on humanitarian values. But in McCarthy's novels, the characters exist outside of traditional humanist categories. The characters create for themselves, a world devoid of humanist values and ethics. In his novel, Child of God McCarthy has Ballard 
disrupt the normalcy of the world around him. Ballard's ambiguity also undoes the readers' categories for a protagonist. Ballard becomes a case study in what novels usually say the human is while McCarthy's novel refuses to categorize Ballard as such (Hage 43). McCarthy plunges us into a violent man's story and forces us to come to terms with how we need to undo our old definitions of the human. In Lester Ballard's existence and in the inadequacy of Sevier County definitions, McCarthy moves us outside our known boundaries of the "human."

In Blood Meridian, the departure from humanistic conventions is almost complete. Glanton's gang and Judge Holden, perpetrate mindless acts of violence that appear revolting by human standards. But again, we have to keep in mind the fact that they have abandoned the humanist code of existence. They have chosen their own path to freedom and independence. But The Kid is an exception. Though he gets a chance to kill Judge Holden, he fails to do so. He is not completely free of his humanist roots. Violence can be interpreted as the law of nature. The transition forces his characters to reevaluate their concepts of life, death, and truth as they struggle to meet their needs and fulfill their dreams. Maturity on the part of the characters is defined by an understanding of the natural order as violent and the concept of evil as an invention of human morality that has no place in the primordial workings of the earth (Greenwood 31). McCarthy insinuates in his novels that once social constraints fall away humanity descends to a primitive violence ordaining the survival of the fittest. Yet the violence coexists with the virtues. The idea of freedom and independence in the novels of McCarthy conveys a sense of departure from the ethics and moral codes laid down by the society. His post-apocalyptic novel The Road foregrounds an amalgamation of virtue and violence. The events take place in a world that no longer conforms to the humanist tradition. In fact most of his novels are concerned with the idea of radical humanism. McCarthy presents a scenario, where human survival is the most significant matter. 
The concepts of virtue and violence are no longer defined by conventional standards. The Father in The Road presents a picture where the child is the warrant for his actions. His sole concern is the welfare of his son. As a consequence of which he commits violent acts. He is not governed by any moral codes. In a radical humanist perspective, he has already taken the independent path. The child on the other hand is a symbol of untarnished humanity, with an idealized vision of good and evil. But in order to survive, he must be beyond good and evil. He must be free to pursue his own course. In a Darwinian world, where only the fittest can survive, the characters are no longer hindered by humanistic ideals. Abandoning humanism, they follow the course of radical humanism, searching for freedom and individuality. Endowed with this sense of freedom, the characters can independently act along the lines of virtue or violence.

McCarthy's world of ruined human values forms the foundation of radical humanism. Radical humanism is not concerned with materialism and idealism. Instead it calls for the freedom of the individual. Across his novels, we trace the journeys of the characters who move away from the defined ways of materialism and idealism. They attempt to chart their own course by existing along the borders of the society and living outside the social laws. Lester Ballard dwells in a cave, without ever bothering about materialistic pursuits like money. McCarthy does not create Utopias based on goodness and virtues. He creates bleak worlds, where the moral compass is ever shifting. Virtue goes hand in hand with violence. The acts are not darkly evil; they are natural. The characters act according to their nature, as their sense of freedom permits them. This scene depicting the end of Blevins in All the Pretty Horses, reveals much about McCarthy's depiction of his characters with their moral orders experiencing with disbelief the reality of the natural order into which they have journeyed. John Grady and Rawlins cannot believe that the consequences of Blevins' actions will be dealt to him in so abrupt and brutal a fashion. Yet this scene and the action 
which leads to it take place in a McCarthy wilderness setting, a place removed from the law and morality of society and the cause and effect framework to which the boys are accustomed. Because of the detachment between their perception of moral truth and its reality outside the confines of their social order, the boys experience shock when Blevins is dealt with in a primitive fashion and simply executed for his crimes.

Radical humanism lays a great amount of emphasis on the personality of the individual. Society is no longer at the forefront of human existence. Almost all of McCarthy's novels are set beyond the boundaries of the conventional society. Hence, the abstract nature of virtue and violence can be explained by the characters' ideals concerning humanism and their ability to free themselves from the codes imposed by the society. There is a continuous and cyclical interaction between the elements of virtue, violence and radical humanism.

\section{Conclusion}

The moral ambiguity pertaining to virtue and violence can be ascribed to the radical humanism. The characters make a departure from conventional humanism and live in a world where survival is the order of the day. The moral codes are no longer binding as the characters chart their own course living beyond the norms laid down by the society. The moral compass is continually shifting for the characters. If John Grady Cole in All the Pretty Horses is horrified by violence and evil, then someone like Judge Holden revels in it. The collapse of humanist values leads to the emergence of a world that is dystopian, a place where the characters are beyond good and evil. Their pursuit of radical humanism allows them to formulate their own codes relating to virtue and violence. 


\section{References}

Primary sources

McCarthy, Cormac. Child of God. New York: Random House USA INC, 2010. Print.

McCarthy, Cormac. Blood Meridian. New York: Random House USA INC, 2015. Print.

McCarthy, Cormac. All the Pretty Horses. London: Picador, 2018. Print.

McCarthy, Cormac. The Crossing. London: Picador, 2018. Print.

McCarthy, Cormac. Cities of the Plains. London: Picador, 2018. Print.

McCarthy, Cormac. No Country for Old Men. London: Picador, 2008. Print.

McCarthy, Cormac. The Road. London: Picador, 2009. Print.

Secondary sources

Arnold, Edwin T. and Dianne C. Luce, ed. A Cormac McCarthy Companion- The Border Trilogy. Jackson, University Press of Mississippi, 2001. Print.

Bloom, Harold, ed. Bloom's Modern Critical Views Cormac McCarthy. New York, Infobase Publishing, 2009. Print.

Durkin, Kieran. The Radical Humanism of Erich Fromm. New York: Palgrave Macmillan, 2014. Print.

Fromm, Erich. You Shall Be As Gods. New York: Fawcett Premier, 1966. Print.

Greenwood, Willard P. Reading Cormac McCarthy. California, Greenwood Press, 2009. Print. Hage, Erik. Cormac McCarthy A Literary Companion. North Carolina: McFarland and Company, 2010. Print.

Hawkins, Ty. Cormac McCarthy’s Philosophy. North Carolina: Palgrave Macmillan, 2017. Print. Lincoln, Kenneth. Cormac McCarthy American Canticles. New York: Palgrave Macmillan, 2009. Print. 